\title{
A Note on Electron Micrographs of Normal and Tyrocidin-lysed Streptococci
}

\author{
By P. D. MITCHELL AND G. R. CROWE \\ Biochemistry Department and the Cavendish Laboratory, Cambridge
}

As shown in the foregoing the sterilization of streptococci (Lancefield Group D) by tyrocidin occurs concomitantly with the leakage of amino-acids from the internal environment. The leakage of the amino-acids is ascribed to changes in the barrier which normally confines them within the cell. It is of interest to consider the nature of this barrier and the site of action of the tyrocidin in disrupting it. Electron microscopy provides the most direct information.

Electron micrographs. A large number of normal and tyrocidin-treated streptococci were observed on the fluorescent screen of the RCA upright electron microscope at magnification 1800. Photographs were taken of the following preparations:

(i) Normal streptococci suspended in dust-free distilled water at a concentration of $20,000 / \mathrm{cu}$. $\mathrm{mm}$. for mounting on the collodion membrane. Pl. 1, figs. 1 and 2, show the normal cocci. The cell wall is very clearly seen as a cortical layer relatively transparent to the electron beam.

(ii) Streptococci treated with $1 \mathrm{mg}$. of tyrocidin $/ 50 \mathrm{mg}$. dry weight and suspended in dust-free distilled water for mounting as above. Pl. 1, figs. 3 and 4 show the lysed cocci. The cell wall is completely disrupted.

The simplest hypothesis which may be proposed to account for the action of tyrocidin supposes that the amino-acid confining barrier is the cell membrane, and that this is disrupted by the entry of the highly surface-active tyrocidin. This cannot be the true mechanism, for the photographs show that tyrocidin does not disrupt only the cell membrane: the cell wall is disrupted. Presumably, either the cell wall is itself the amino-acid confining barrier, or, being attached to the cell membrane or some other confining structure, this is disrupted with it. In any case, it is certain that rupture of the cell wall is concomitant with the leakage of the amino-acids from the tyrocidin-treated cocci.

\section{EXPLANATiON OF PLATE}

Fig. 1. Normal streptococci.

Fig. 2. Normal Diplococcus.

Fig. 3. Tyrocidin-lysed streptococci. Note the cell wall trailing away in some places. Compare Fig. 1.

Fig. 4. Tyrocidin-treated Diplococcus. Note the cell wall gathered into cleavage furrow. Compare Fig. 2. 
Journal of General Microbiology, Vol. 1, No. 1

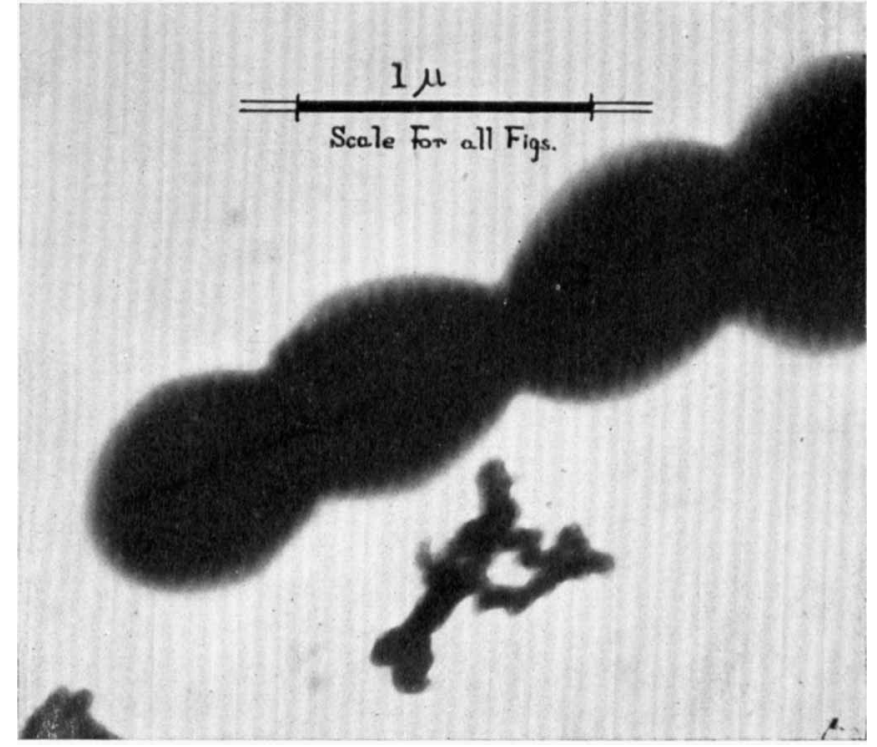

Fig. 1

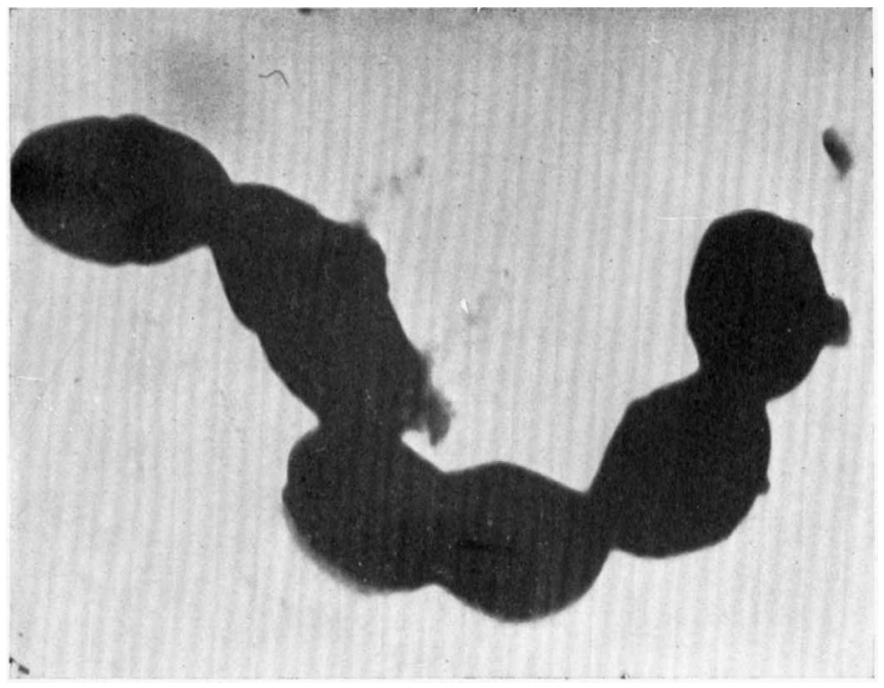

Fig. 3

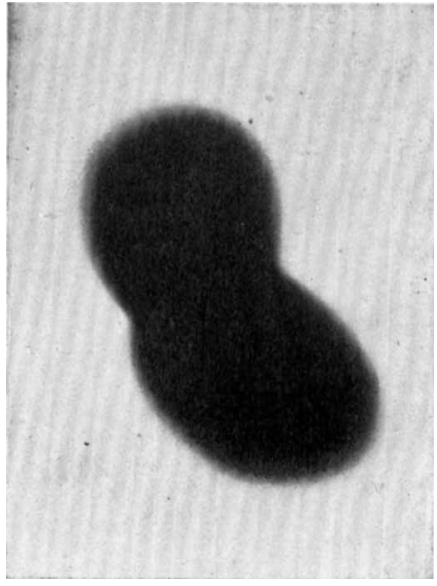

Fig. 2

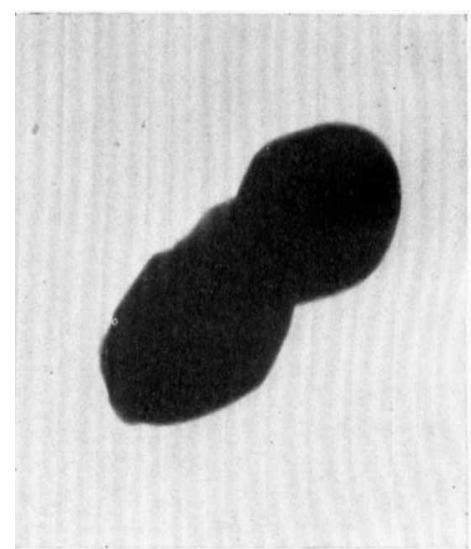

Fig. 4

E. F. Gale and E. S. Taylor-Cell wall damage, Plate 1 ; P. D. Mitchell and G. R. CroweELECTRON MICROGRAPHS OF NORMAL AND TYROCIDIN-LYSED STREPTOCOCCI 